\title{
REMOVED: THE ARGUMENT STYLE OF RESEARCH ARTICLE DISCUSSIONS BY NON-NATIVE AUTHORS OF ENGLISH PUBLISHED IN INTERNATIONAL JOURNALS
}

Safnil Arsyad1; Muhammad Zaim²; Syahrul Ramadhan³; Azhar Aziz Lubis ${ }^{4}$

$$
\text { Universitas Bengkulu1,4; Universitas Negeri Padang }{ }^{2,3}
$$

This article has been removed at the request of Professor Safnil Arsyad because the criteria for research output required by the research funder have yet to fulfil. 
Removed 
Removed 
Removed 
Removed 
Removed 
Removed 
Removed 
Removed 
Removed 
Removed 
Removed 
Removed 
Removed 
Removed 
Removed 
Removed 
Removed 
Removed 